\title{
Biguanide-Based Synthesis of 1,3,5-Triazine Derivatives with Anticancer Activity and 1,3,5-Triazine Incorporated Calcium Citrate Nanoparticles
}

\author{
Monnaya Chalermnon ${ }^{1}$, Sarocha Cherdchom ${ }^{2,3}{ }^{\mathbb{D}}$, Amornpun Sereemaspun ${ }^{4}$, Rojrit Rojanathanes ${ }^{5}$ \\ and Tanatorn Khotavivattana ${ }^{6, *(D)}$
}

check for

updates

Citation: Chalermnon, M.; Cherdchom, S.; Sereemaspun, A.; Rojanathanes, R.; Khotavivattana, T. Biguanide-Based Synthesis of 1,3,5-Triazine Derivatives with Anticancer Activity and 1,3,5-Triazine Incorporated Calcium Citrate Nanoparticles. Molecules 2021, 26, 1028. https://doi.org/10.3390/ molecules26041028

Academic Editor: Alessia Irerra

Received: 25 January 2021

Accepted: 12 February 2021

Published: 15 February 2021

Publisher's Note: MDPI stays neutral with regard to jurisdictional claims in published maps and institutional affiliations.

Copyright: (c) 2021 by the authors. Licensee MDPI, Basel, Switzerland. This article is an open access article distributed under the terms and conditions of the Creative Commons Attribution (CC BY) license (https:/ / creativecommons.org/licenses/by/ $4.0 /)$.
1 Department of Chemistry, Faculty of Science, Chulalongkorn University, Bangkok 10330, Thailand; monnayach@yahoo.com

2 Department of Pharmacy Practice, Faculty of Pharmaceutical Sciences, Chulalongkorn University, Phayathai Road, Wangmai, Patumwan, Bangkok 10330, Thailand; sarocha.cherdchom@gmail.com

3 NanoMedicine Research Unit, Department of Anatomy, Faculty of Medicine, Chulalongkorn University, Rama 4 Road, Patumwan, Bangkok 10330, Thailand

4 Chula Medical Innovation Centre (CMIC), Nanomedicine Research Unit, Department of Anatomy, Faculty of Medicine, Chulalongkorn University, Bangkok 10330, Thailand; amornpun.s@gmail.com

5 Centre of Excellence in Materials and Bio-Interfaces, Faculty of Science, Chulalongkorn University, Bangkok 10330, Thailand; rojrit@hotmail.com

6 Centre of Excellence in Natural Products Chemistry, Department of Chemistry, Faculty of Science, Chulalongkorn University, Bangkok 10330, Thailand

* Correspondence: tanatorn.k@chula.ac.th; Tel.: +66-2-218-7621

\begin{abstract}
Twelve derivatives of biguanide-derived 1,3,5-triazines, a promising class of anticancer agent, were synthesised and evaluated for their anticancer activity against two colorectal cancer cell lines-HCT116 and SW620. 2c and 3c which are the derivatives containing $o$-hydroxyphenyl substituents exhibited the highest activity with $\mathrm{IC}_{50}$ against both cell lines in the range of $20-27 \mu \mathrm{M}$, which is comparable to the $\mathrm{IC}_{50}$ of cisplatin reference. Moreover, the potential use of the calcium citrate nanoparticles (CaCit NPs) as a platform for drug delivery system was studied on a selected 1,3,5-triazine derivative 2a. Condition optimisation revealed that the source of citrate ions and reaction time significantly influence the morphology, size and \%drug loading of the particles. With the optimised conditions, "CaCit-2a NPs" were successfully synthesised with the size of $148 \pm 23 \mathrm{~nm}$ and \%drug loading of up to $16.3 \%$. Furthermore, it was found that the release of $2 \mathrm{a}$ from the synthesised CaCit-2a NPs is pH-responsive, and $2 \mathbf{a}$ could be control released under the acidic cancer environment. The knowledge from this study is perceptive for further development of the 1,3,5triazine-based anticancer drugs and provide the platform for the incorporation of other drugs in the CaCit NPs in the future.
\end{abstract}

Keywords: 1,3,5-triazine; anticancer; calcium citrate; nanoparticles

\section{Introduction}

Cancer is a devastating disease with an increasing number of diagnosis and death every year. In 2019, there were more than 1 million new cases, especially prostate, breast, lungs and colorectal cancer [1]. Chemotherapy is one of the most frequently used treatment methods despite several limitation of the currently available drugs including poor drug selectivity, potential drug resistance and possibilities for recurrences [2]. In order to mitigate these limitations, the development of a new anticancer agent with an efficient delivery system is necessary [3]. The 1,3,5-triazine scaffold has been reported to possess many biological activities especially anticancer activity [4]. A variety of synthetic routes exists for the 1,3,5-triazine derivatives, for example, three-component methods [5,6] or reactions between biguanides with alcohol [7,8], amide [9] or carboxylic acid derivatives [10,11]. As 
seen in many literatures, a biguanide like metformin has been frequently employed as the starting material $[8,10,12,13]$. Metformin-derived 1,3,5-triazine derivative HL010183 was shown to be 100 times more cytotoxic than metformin with $\mathrm{IC}_{50}$ of $0.28 \mathrm{mM}$ for both MDA-MB-231 and Hs578T cell lines [14]. 1,3,5-Triazine synthesised from various other aryl-biguanides were also reported as Rad6 ubiquitin-conjugating enzymes inhibitors and they exhibited anticancer activity in the low micromolar range [15]. It is therefore very intriguing to explore new structural modifications of 1,3,5-triazine derivatives to further enhance the anticancer activity of this scaffold. However, one limitation of 1,3,5-triazine is its ability to reach the target site which would affect its anticancer activity [4]. In 2016, one example of the drug delivery system (DDS) was reported by coupling the 1,3,5-triazine derivatives with bovine serum albumin in order to solve this issue [4].

DDS is a safe and efficient way to deliver drug while enhancing the therapeutic efficiency and reducing side effects. Nanoparticles acting as drug carriers could benefit from the enhanced permeability and retention (EPR) effect because cancer cells have leaky vasculatures and an impaired lymphatic system [16]. One influential aspect of the EPR effect is particles sized $30-300 \mathrm{~nm}$, which has been reported as a suitable range. Particle size outside of this range are prone to rapid clearance by the mononuclear phagocyte system $[17,18]$. Additionally, the leakiness of tumour vessel could dictate the selectivity of nanoparticles towards cancer cells. Another prominent characteristic of cancer cells is their relatively lower $\mathrm{pH}$ environment compared to normal cells, therefore $\mathrm{pH}$-responsive nanoparticles would further reinforce the usefulness of nanoparticles for drug delivery system [19]. Recently, our group has shown a potential use of calcium citrate nanoparticles, a biocompatible and biodegradable material $[20,21]$, as a promising platform for DDS. Vancomycin, an antibiotic drug for bone spacer application, was successfully encapsulated in the calcium citrate particles (VAN-CC) with a size of around $500 \mathrm{~nm}$ and an encapsulation efficiency of $28 \%$ [22]. In another work, FITC, a fluorescent agent, was encapsulated and slowly released from calcium citrate nanoparticles as experimented with human keratinocytes [23].

Herein, we report the synthesis and anticancer activities of biguanide-derived 1,3,5triazine derivatives bearing various substituents on the triazine scaffold. Furthermore, the DDS based on the incorporation of a selected 1,3,5-triazine derivative into calcium citrate nanoparticles was investigated (Figure 1). We hypothesised that the nanoparticles would benefit from the EPR effect as well as be $\mathrm{pH}$-responsive and control released drug under the acidic cancer environment.

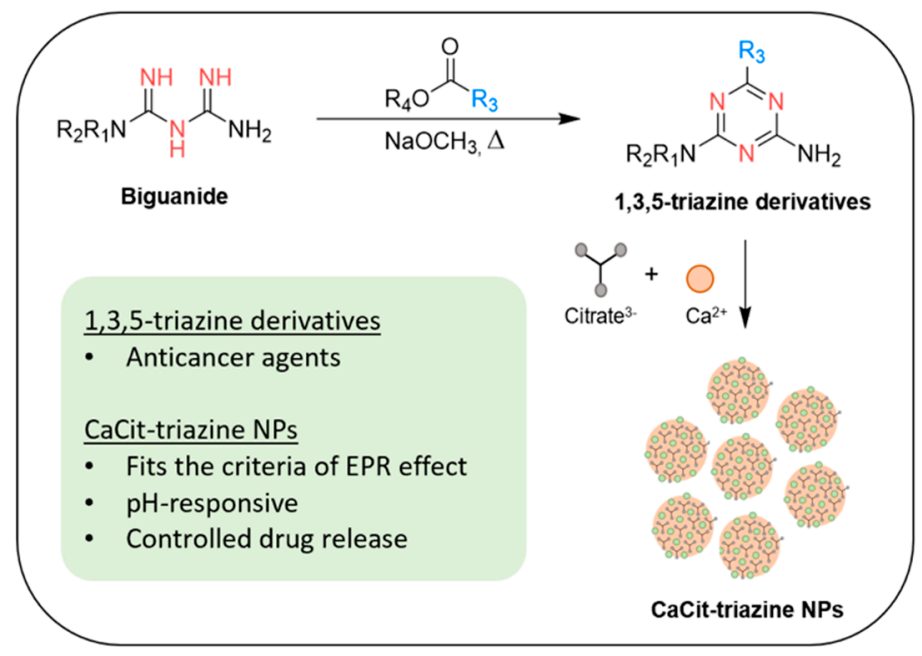

Figure 1. Synthesis and incorporation of biguanide-derived 1,3,5-triazine derivatives in calcium citrate nanoparticles (this work). 


\section{Results and Discussions}

\subsection{Chemistry}

1,3,5-Triazine derivatives of metformin (2a-2f) and phenylbiguanide (3a-3f) were synthesised by the condensation between a biguanide and an ester. Metformin hydrochloride was used as purchased, but phenylbiguanide hydrochloride (1a) was prepared according to the previously reported method using aniline and dicyandiamide in excellent yield [24]. The five esters included in this work were isopropyl palmitate $\left(\mathrm{R}_{3}=\mathrm{C}_{15} \mathrm{H}_{31}\right)$, methyl benzoate $\left(\mathrm{R}_{3}=\mathrm{Ph}\right)$, methyl salicylate $\left(\mathrm{R}_{3}=\mathrm{Ph}-\mathrm{o}-\mathrm{OH}\right)$, methyl cinnamate $\left(\mathrm{R}_{3}=\mathrm{C}=\mathrm{CH}-\mathrm{Ph}\right)$ and diethyl oxalate $\left(\mathrm{R}_{3}=\mathrm{COOC}_{2} \mathrm{H}_{5}\right)$. Initially, a one-pot reaction containing a biguanide hydrochloride, an ester and sodium methoxide (NaOMe) in methanol was used $[10,15,24,25]$. After reaction optimisation by adjusting the ratio of reagents and reaction time, $\mathbf{2 a}, \mathbf{2} \mathbf{b}, \mathbf{2 d}$, $2 \mathbf{f}$ and 3a were obtained in moderate yields (Figure 2, Pathway I). However, the synthetic yields of other derivatives were very low. Carboxylic by-products of the ester starting materials were detected even though anhydrous solvent and inert atmosphere were implemented. We hypothesised that this could be due to the presence of base and water in the reaction mixture simultaneously. Therefore, the method was slightly adjusted by starting with the neutralisation step to generate biguanide in the free base form $[10,15,24,25]$. Then the biguanide was isolated and reacted with an ester without the use of the additional base (Figure 2, Pathway II). As a result, $\mathbf{2 c}, \mathbf{2} \mathbf{e}$ and $\mathbf{3 b} \mathbf{b}-\mathbf{3} \mathbf{f}$ were successfully synthesised with low to moderate yields. In total, 12 1,3,5-triazine derivatives were obtained, of which four compounds were novel (2e, 2f, 3d, 3f); three compounds have been reported, but not fully characterised (2c, 3a, 3c); and five compounds were known ( $2 \mathbf{a}, \mathbf{2 b}, \mathbf{2 d}, \mathbf{3 b}, \mathbf{3 e})$. The structures of all 1,3,5-triazine derivatives were elucidated by ${ }^{1} \mathrm{H}$ and ${ }^{13} \mathrm{C}-\mathrm{NMR}$ spectroscopy. In addition, the novel and not fully characterised derivatives were further characterised for IR spectra, mass spectra and melting points as the information has yet been reported (see Supplementary Materials).

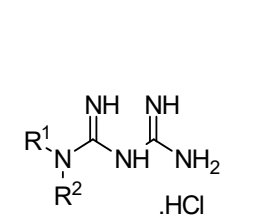

Metformin $\mathrm{HCl}: \mathrm{R}^{1}, \mathrm{R}^{2}=\mathrm{CH}_{3}$ 1a: $\mathrm{R}^{1}=\mathrm{Ph}, \mathrm{R}^{2}=\mathrm{H}$

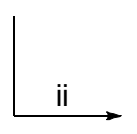<smiles>[1H]c1nc(N)nc(N(C)C)n1</smiles>

2a-2f<smiles>Nc1nc(N)nc(Nc2ccccc2)n1</smiles>

3a-3f

\section{[Pathwayl]}
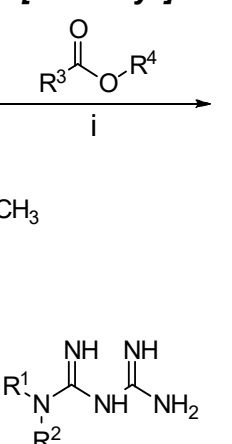

$$
\frac{\text { iii }}{\mathrm{R}^{\mathrm{O}^{-}} \mathrm{R}^{4}}
$$

[Pathway II]

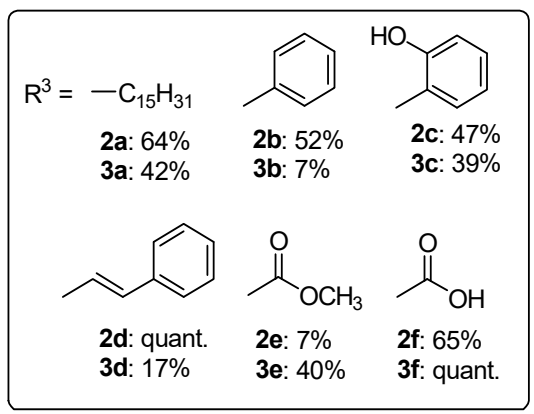
(i) Ester (1-3 equiv.),

$\mathrm{NaOMe}$ (1-5 equiv.), anh. $\mathrm{MeOH}$, reflux; (ii) NaOMe (1 equiv.), anh. $\mathrm{MeOH}$, rt.; (iii) ester (1-excess equiv.), anh. MeOH.

\subsection{In Vitro Anticancer Activities}

The in vitro anticancer activities of $\mathbf{2 a}-\mathbf{2} \mathbf{f}$ and $\mathbf{3 a} \mathbf{a}-\mathbf{3} \mathbf{f}$ were evaluated against two colon cancer cell lines to assess the influence of synthesised 1,3,5-triazine derivatives on cellular viability (Table 1). Anticancer studies of 1,3,5-triazine derivatives is extensive, but only a few studies had performed their evaluations with HCT116 and SW620 cell lines [26,27]. Cisplatin was used as a positive control and the result was consistent with reported literature value [28]. Initially, a preliminary screening of the cytotoxicity was performed on all twelve 1,3,5-triazine derivatives at a specific concentration of $100 \mu \mathrm{M}$. All of the synthesised 1,3,5-triazine derivatives were active at varied abilities, and some exhibited comparable or higher cytotoxicity than cisplatin for both cell lines. The comparison of the cytotoxicity of these compounds at $100 \mu \mathrm{M}$ showed that the hydrophobic substituents re- 
sulted in higher cytotoxicity than hydrophilic groups as reflected in the two most cytotoxic compounds: 2a with the long alkyl substituent (\%cytotoxicity $=96.02 \pm 0.06$ (SW620) and $67.43 \pm 1.82$ (HCT116)) and 3d with the aryl group (87.47 \pm 1.54 (SW620) and $92.27 \pm 0.04$ (HCT116)). In contrast, the \%cytotoxicity of $\mathbf{2 b}$ with phenyl substituent, $\mathbf{2 e} / \mathbf{3 e}$ with the ester substituent and $\mathbf{2} \mathbf{f} / \mathbf{3} \mathbf{f}$ with the carboxylic substituents were very low in the range of $5-20 \%$. Overall, the 1,3,5-triazine that are derived from the phenylbiguanide (3a-3f) showed significantly higher cytotoxicity compared with ones derived from the metformin (2a-2f). These results established a relationship between the increased hydrophobicity with enhanced cytotoxicity, but the reason for this relation do need further investigation. From the \%cytotoxicity values, 2 a was selected for the further study on the drug incorporation using calcium citrate nanoparticles.

Table 1. Anticancer activities of synthesised 1,3,5-triazine derivatives.

\begin{tabular}{|c|c|c|c|c|}
\hline \multirow{2}{*}{ 1,3,5-Triazine Derivatives } & \multicolumn{2}{|c|}{$\%$ Cytotoxicity at $100 \mu \mathrm{M}^{1}$} & \multicolumn{2}{|c|}{$\mathrm{IC}_{50}(\mu \mathrm{M})^{2}$} \\
\hline & SW620 & HCT116 & SW620 & HCT116 \\
\hline $1 \mathrm{a}$ & n.a. ${ }^{3}$ & n.a. ${ }^{3}$ & n.d. 4 & n.d. 4 \\
\hline $2 a$ & $96.02 \pm 0.06$ & $67.43 \pm 1.82$ & $59.13 \pm 1.46$ & $59.35 \pm 1.66$ \\
\hline $2 b$ & $15.86 \pm 1.91$ & $19.23 \pm 5.94$ & n.d. & n.d. \\
\hline $2 c$ & $53.85 \pm 1.40$ & $50.77 \pm 1.83$ & $25.25 \pm 1.12$ & $26.29 \pm 1.07$ \\
\hline $2 d$ & $27.39 \pm 4.16$ & $26.52 \pm 3.77$ & n.d. ${ }^{4}$ & n.d. ${ }^{4}$ \\
\hline $2 e$ & $11.41 \pm 3.52$ & $7.16 \pm 2.11$ & n.d. ${ }^{4}$ & n.d. ${ }^{4}$ \\
\hline $2 f$ & $5.64 \pm 1.51$ & $11.59 \pm 4.03$ & n.d. 4 & n.d. 4 \\
\hline $3 a$ & $54.96 \pm 1.46$ & $66.56 \pm 2.58$ & $54.55 \pm 1.09$ & $59.17 \pm 1.48$ \\
\hline $3 b$ & $52.60 \pm 4.06$ & $54.42 \pm 8.48$ & $38.37 \pm 1.05$ & $26.92 \pm 1.31$ \\
\hline $3 c$ & $56.85 \pm 3.18$ & $65.46 \pm 1.07$ & $22.80 \pm 1.06$ & $20.79 \pm 1.07$ \\
\hline $3 d$ & $87.47 \pm 1.54$ & $92.27 \pm 0.04$ & $54.10 \pm 1.05$ & $55.02 \pm 1.04$ \\
\hline $3 e$ & $12.14 \pm 3.40$ & $5.54 \pm 3.65$ & n.d. ${ }^{4}$ & n.d. ${ }^{4}$ \\
\hline $3 f$ & $15.36 \pm 1.15$ & $14.22 \pm 2.81$ & n.d. ${ }^{4}$ & n.d. ${ }^{4}$ \\
\hline Cisplatin & $62.14 \pm 5.05$ & $78.20 \pm 0.96$ & $31.67 \pm 1.13$ & $19.18 \pm 1.06$ \\
\hline
\end{tabular}

${ }^{1}$ Results expressed in percentage taken as a mean of triplicates \pm standard deviation (SD). ${ }^{2}$ Results expressed in $\mu \mathrm{mol} / \mathrm{L}(\mu \mathrm{M})$, taken as a mean value of triplicates \pm standard deviation (SD). ${ }^{3}$ Not active at the specified.

${ }^{4}$ Not determined.

Six compounds with high \%cytotoxicity were selected for further evaluation by varying the concentration between $0-100 \mu \mathrm{M}$ to calculate the $50 \%$ cell-growth inhibition ( $\mathrm{IC}_{50}$ ) values. (see Supplementary Materials) The most potent anticancer agents were 2c and 3c, both having the $o$-hydroxyphenyl substituent with the $\mathrm{IC}_{50}$ of $25.25 \pm 1.12 \mu \mathrm{M}$ and $22.80 \pm 1.06 \mu \mathrm{M}$ for SW620 cell line, and at $26.29 \pm 1.07 \mu \mathrm{M}$ and $20.79 \pm 1.07 \mu \mathrm{M}$ for HCT116 cell line, respectively. These $\mathrm{IC}_{50}$ values of $2 \mathrm{c} / 3 \mathrm{c}$ were comparable and slightly better than the reference drug, cisplatin. Even though the synthesised compounds are yet novel, the activity of $2 \mathrm{c}$ or $3 \mathrm{c}$ compared to the previously reported 1,3,5-triazine derivatives with alike substituents and size, for example, HL010183 or 4-amino-6-(arylamino)-Nphenyl-1,3,5-triazine-2-carbohydrazides, could be considered as decent competitors [14,29].

\subsection{1,3,5-Triazine Incorporated Calcium Citrate Nanoparticles}

Despite the successful drug encapsulation in calcium citrate nanoparticles [23], the method was not applicable for the incorporation of $\mathbf{2 a}$. This was due to the use of water as the only solvent in the system, leading to poor solubility of triazine drugs. Therefore, we attempted to optimise the protocol for the preparation of 1,3,5-triazines-incorporated calcium citrate nanoparticles (CaCit-triazine NPs) using EtOH-water as a binary solvent system, adjusted from the synthesis of calcium carbonate particles previously reported [30]. There are many methods to prepare calcium citrate particles, but the two most common reagents are $\mathrm{CaCl}_{2}$ and sodium citrate [21,23,31]. In our first attempt, a solution of $\mathrm{CaCl}_{2}$ in EtOH was slowly added to a solution of $\mathbf{2 a}$ and sodium citrate in EtOH-water under vigorous stirring at room temperature. Unfortunately, the obtained product was large 
precipitate particles of $\mathbf{2 a}$ as confirmed by SEM and FTIR, and the desired CaCit-triazine NPs was not observed, since there was no IR signal characteristic to calcium citrate, i.e., $3400 \mathrm{~cm}^{-1} \mathrm{O}-\mathrm{H}$ stretching or peaks in the carbonyl group stretching region (Figure 3c). This was due to the basicity of $\mathbf{2 a}$ and sodium citrate [32]. In alkali condition, calcium ions have more affinity towards hydroxide than citrate ions, thus allowing the possibility to form calcium hydroxide instead of calcium citrate precipitate [33]. Alternatively, calcium citrate could be prepared via acid-base reaction between citric acid and calcium hydroxide or calcium carbonate [34]. We decided to generate citrate ions in situ from the reaction between citric acid and $\mathrm{NaOH}$ preventing the formation of calcium hydroxide in elevated $\mathrm{pH}$. The $\mathrm{pH}$ of citric acid solution was adjusted to $\mathrm{pH} 6.0$ using 1:2 mole ratio of citric acid to $\mathrm{NaOH}$ resulting in citrate ions in the divalent form [35]. Both the selected $\mathrm{pH}$ value and the divalent form of citrate ions have been reported to allow the formation of calcium citrate [32]. The FTIR spectrum of product obtained from using citric acid with $\mathrm{NaOH}$ exhibited characteristic peaks of both calcium citrate $\left(3452,1543,1429\right.$ and $1081 \mathrm{~cm}^{-1}$ ) and 2a $\left(2920,2851,1570,817,804\right.$ and $\left.720 \mathrm{~cm}^{-1}\right)$ as depicted in Figure 3d. Even though citric acid with $\mathrm{NaOH}$ could perform as the source of citrate, the obtained particles were aggregated and not nano-sized. Further reaction optimisation continued with the study of the effect of reaction time.

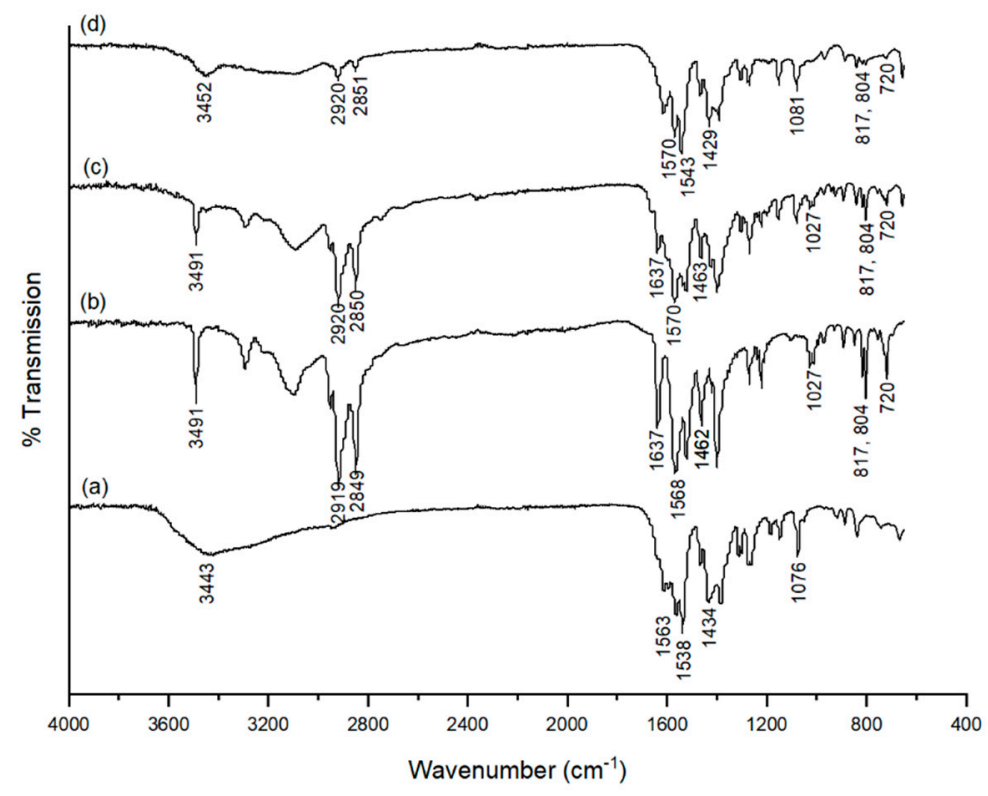

Figure 3. FTIR spectra of (a) calcium citrate nanoparticles, (b) 2a, (c) reaction using sodium citrate and (d) reaction using citric acid with $\mathrm{NaOH}$.

Reaction time significantly influence the morphology and size of particles. SEM images in Figure 4 show a general trend that particle grew larger with longer reaction time. Iafisco et al. has reported a similar finding stating that longer reaction time caused a growth on the c-axis of citrate-apatite particles resulting in long needle-like morphology [36]. Regardless of the trend, nanoparticles were obtained at two reaction times, at the second (Figure 4ii) and the eighth hour (Figure $4 \mathrm{v}$ ). This complication on the nanostructure formation emerged from having both the crystallisation of calcium citrate and the absorption of 2a occurring as well as the presence of ethanol. The experiment was verified again with the exact same reaction condition at 2,5 and $8 \mathrm{~h}$ (Table 2). We suspect that the obtained nanoparticles at $2 \mathrm{~h}$ was the kinetic product that undergo phase change and reassembled into more thermodynamically favourable nanoparticles at $8 \mathrm{~h}$. The phase change with respect to time is observed in calcium carbonate, where the amorphous calcium carbonate transforms into more stable vaterite then calcite over time [37]. The double nanoparticle formations could also be attributed to the presence of ethanol in the reaction. Ethanol was found to be able to stabilise vaterite phase of calcium carbonate preventing its rapid 
transformation to calcite. We suppose that this could be the case where the prior nanoparticles formation was maintained long enough to be observed by SEM [38]. The synthesised nanoparticles obtained from condition $\mathrm{A}$ and condition $\mathrm{C}$ had size consistent with those particles presented in Figure 4, but nanoparticles from condition A was slightly smaller than condition $C$ at around $130 \mathrm{~nm}$ and $150 \mathrm{~nm}$, respectively (Table 2). For condition $\mathrm{B}$, the obtained particles were aggregated and plate-like with particle size over $1000 \mathrm{~nm}$. Dynamic light scattering results also showed that the particles were monodispersed for both condition A and condition C, which the hydrodynamic diameter of nanoparticles were found to be in parallel to the SEM size (see Supplementary Materials). However, the values were larger due to the tendency of nanoparticles to agglomerate in aqueous solvent [39]. As the size of nanoparticles synthesised were between 300-370 nm, they still correspond to the desired size for nanoparticles to take advantages of the EPR effect.
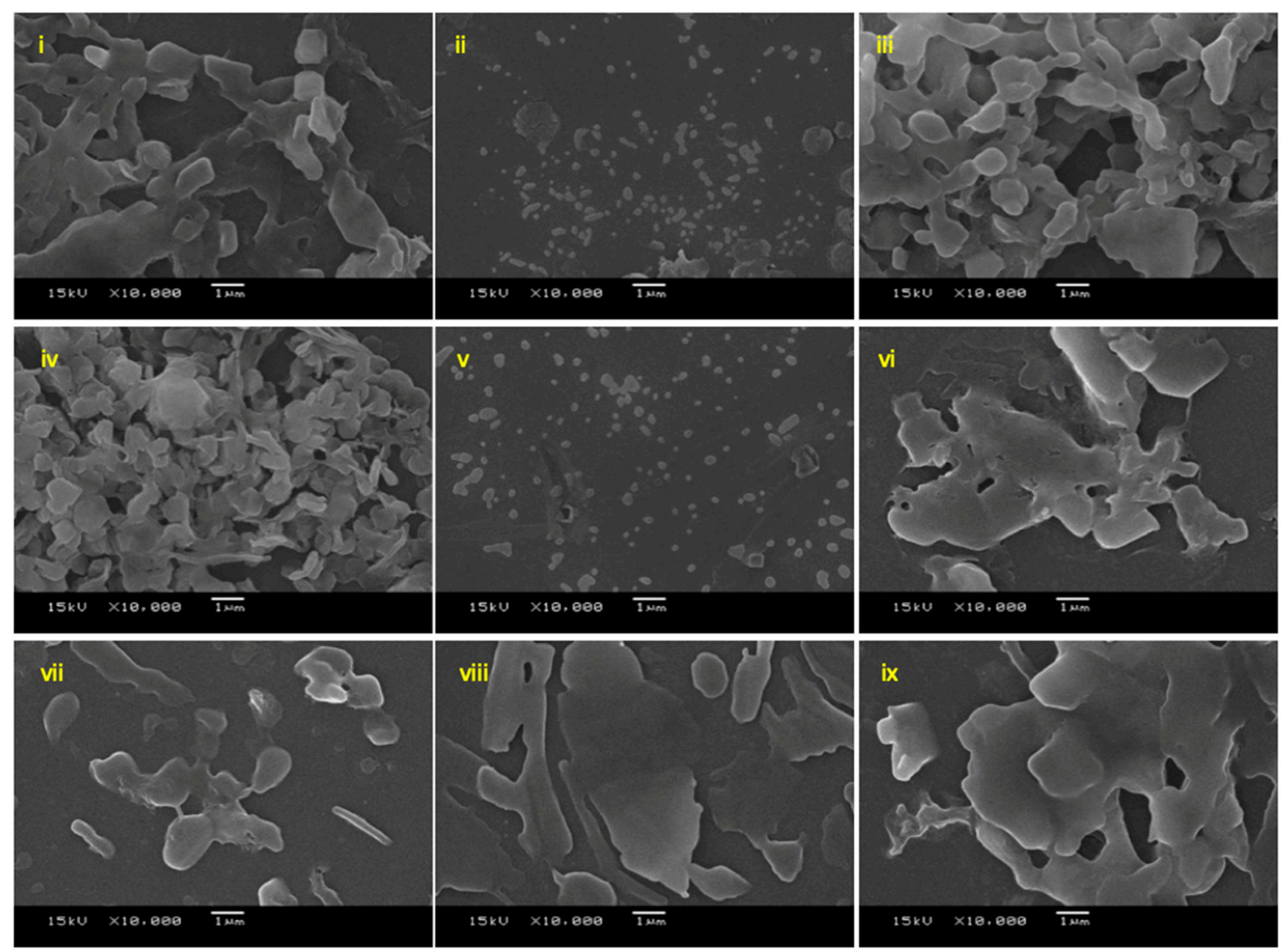

Figure 4. SEM images of CaCit-triazine at various synthesis time between $1-24 \mathrm{~h}$ at $10,000 \times$ magnification; $\mathbf{i}(1 \mathrm{~h})$, ii (2 h), iii (4 h), iv (6 h), v (8 h), vi (12 h), vii (16 h), viii (20 h) and ix (24 h).

The extent of drug incorporation in calcium citrate nanoparticles from condition A and condition $\mathrm{C}$ was calculated using CHNS elemental analysis. This method was chosen because $2 \mathbf{a}$ was the only compound containing nitrogen, thus the percentage of nitrogen directly indicated the amount of $\mathbf{2 a}$. Condition $\mathrm{B}$ had the highest \%drug loading at $17.8 \%$, followed by condition $C$ and condition $A$ at $16.3 \%$ and $9.6 \%$, respectively. It is noteworthy that despite the similarity of particle size for condition A and C, longer reaction time resulted in a higher \%drug loading. Thermal gravimetric analysis additionally validated the success of drug incorporation. The TGA curves of calcium citrate nanoparticles, $\mathbf{2 a}$ and particles obtained from condition A-C are illustrated in Figure 5. The decomposition of calcium citrate typically occurs in three stages. The first weight loss between $50-170{ }^{\circ} \mathrm{C}$ was caused by the release of exterior and interior water molecules $[21,31]$. The second stage between $420-600{ }^{\circ} \mathrm{C}$ indicated the change of calcium citrate to calcium carbonate. Lastly, the decomposition of calcium carbonate to calcium oxide occurred at temperature beyond 
$700{ }^{\circ} \mathrm{C}$. For $2 \mathrm{a}$, it was almost a one-step decomposition starting at $200{ }^{\circ} \mathrm{C}$. TGA curves of all obtained products (condition A-C) exhibited weight loss behaviours of both calcium citrate and 2a. The weight loss between $50-150{ }^{\circ} \mathrm{C}$ attributed to release of moisture and the decrease in weight after $200{ }^{\circ} \mathrm{C}$ indicated the decomposition of 2a. \%weight loss for condition $\mathrm{A}$ and $\mathrm{C}$ agreed with the \%drug loading calculated by CHNS analysis method at $13.5 \%$ and $15.6 \%$, respectively. Overall, the optimised reaction condition to synthesise CaCit-triazine NPs preferred citric acid with $\mathrm{NaOH}$ as the source of citrate ion with reaction time of $8 \mathrm{~h}$.

Table 2. Characterisation of 1,3,5-triazine incorporated calcium citrate nanoparticles.

\begin{tabular}{|c|c|c|c|c|c|c|}
\hline Condition & $\begin{array}{l}\text { Reaction Time } \\
\text { (h) }\end{array}$ & $\begin{array}{l}\text { SEM Size } \\
\text { (nm) }\end{array}$ & $\begin{array}{l}\text { Particle Size } \\
(\mathrm{nm})[\mathrm{PDI}]\end{array}$ & $\begin{array}{c}\text { Zeta Potential } \\
(\mathrm{mV})\end{array}$ & \multicolumn{2}{|c|}{$\begin{array}{l}\text { Drug Loading } \\
(\%)\end{array}$} \\
\hline A & 2 & $134 \pm 18.87$ & $\begin{array}{c}369.30 \pm 13.44 \\
{[0.464]}\end{array}$ & -8.36 & $9.6^{1}$ & $13.5^{2}$ \\
\hline B & 5 & $>1000$ & n.d. ${ }^{3}$ & n.d. ${ }^{3}$ & $17.8^{1}$ & n.d. ${ }^{3}$ \\
\hline C & 8 & $148 \pm 23.69$ & $\begin{array}{c}300.30 \pm 12.42 \\
{[0.322]}\end{array}$ & -7.71 & $16.3^{1}$ & $15.6^{2}$ \\
\hline $15 \mathrm{kU} \times 2 \theta, \theta$ & & 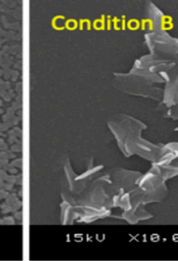 & $\frac{}{1, m}$ & $15 \mathrm{kU} \times 28,800-$ & & \\
\hline
\end{tabular}

$1 \%$ drug loading calculated by CHNS elemental analysis. ${ }^{2} \%$ drug loading calculated by thermal gravimetric analysis. ${ }^{3}$ Not determined.

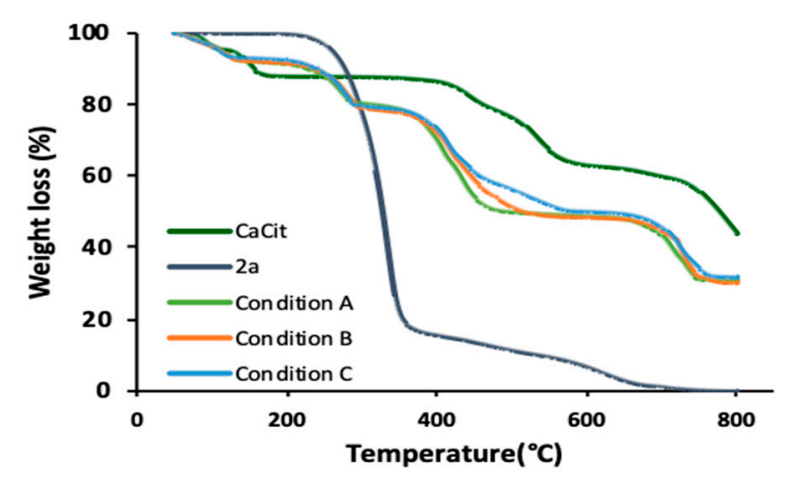

Figure 5. TGA curves of calcium citrate (CaCit), 2a and Condition A-C.

\subsection{In Vitro Drug Release}

The in vitro drug release study revealed that CaCit-2a NPs (condition C) was pHresponsive with controlled drug release behaviour over $48 \mathrm{~h}$. The drug release performance was studied using dialysis method with $30 \%(v / v)$ EtOH in PBS as the release medium to accommodate the release of the hydrophobic 1,3,5-triazine derivative 2a [40]. Typically, the physiological $\mathrm{pH}$ of blood and inside normal tissues is 7.4 and the $\mathrm{pH}$ of the tumour environment is slightly lower at 6.5-6.8 due to the metabolic adaptation called 'Warburg effect' where there is a higher rate of glycolytic metabolism producing an increasing number of protons $\left(\mathrm{H}^{+}\right)$[19]. Moreover, the lysosome of cancer cells has $\mathrm{pH}$ around 4.5 [41]. Therefore, we carried out the drug release at three conditions $(\mathrm{pH}=7.4,5.0$, and 3.0) to study the effect of $\mathrm{pH}$ on the drug release. The general drug release trend illustrated that a higher \%cumulative drug release was found at lower $\mathrm{pH}$ (Figure 6). The difference in drug release was attributed to the higher rate of calcium citrate decomposition in low $\mathrm{pH}$ condition [42]. After $24 \mathrm{~h}, 48.8 \%$ and $30.0 \%$ of $\mathbf{2 a}$ was released for $\mathrm{pH} 5.0$ and $\mathrm{pH} 7.4$, respectively. A two-fold higher drug release was observed for $\mathrm{pH} 3.0$ at $81.6 \%$. The release 
of $2 \mathrm{a}$ was sustained for $48 \mathrm{~h}$ with the release of over half of the nanoparticles' loaded content at $63.9 \%$ for $\mathrm{pH} 5.0$ and to a lesser extent of $41.9 \%$ for $\mathrm{pH} 7.4$. It is probable that $2 \mathrm{a}$ could still be released from CaCit-2a NPs even after $48 \mathrm{~h}$.

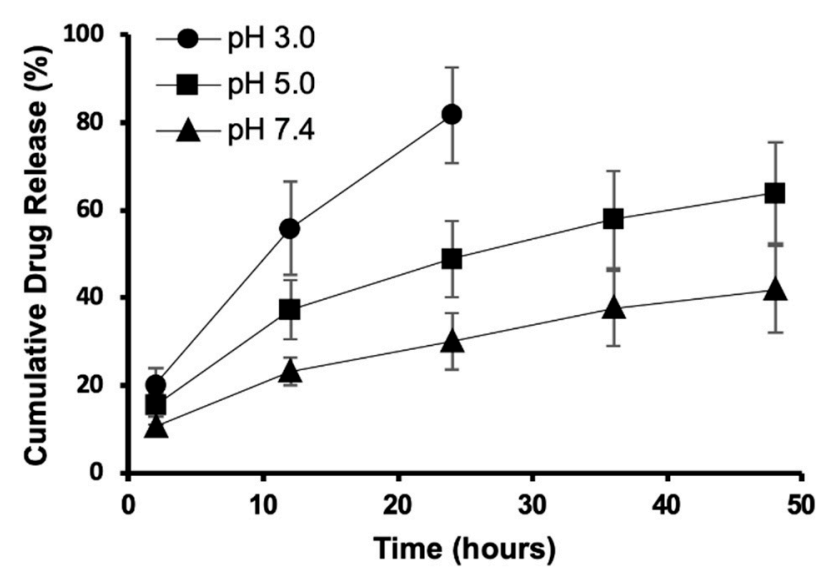

Figure 6. Release profile of 1,3,5-triazine incorporated calcium citrate nanoparticles (Condition C) at $\mathrm{pH} 3.0,5.0$ and 7.4 .

\section{Materials and Methods}

\subsection{Materials}

Metformin hydrochloride and methyl cinnamate were purchased from Fluorochem (Hadfield, Derbyshire, UK); dicyandiamide, aniline, diethyl oxalate, methyl salicylate and sodium methoxide were purchased from TCI Chemical (Tokyo, Japan); isopropyl palmitate was purchased from Sigma Aldrich (St. Louis, MO, USA); methyl benzoate was gifted by the Department of Chemistry, Chulalongkorn University. Calcium chloride dihydrate and trisodium citrate dihydrate were purchased from Merck (Darmstadt, Germany). Citric acid anhydrous was purchased from Loba Chemie PVT. LTD (Mumbai, India). All of solvents used were distilled or analytical grade.

HCT116 (Human colorectal carcinoma) and SW620 (Human colorectal adenocarcinoma) cells were obtained from Nanomedicine RU, Faculty of Medicine, Chulalongkorn University. DMEM (Dulbecco's Modified Eagle Medium), RPMI, fetal bovine serum (FBS), antibiotics, trypsin-EDTA, PBS (Phosphate Buffered Saline) (1X, pH 7.4) and Prestoblue ${ }^{\mathrm{TM}}$ cell viability reagent were purchased from Thermo Fisher Scientific (Waltham, MA, USA). Cisplatin was purchased from Sigma Aldrich (St. Louis, MO, USA) and dialysis bag Spectra/Por membranes $(\mathrm{MWCO}=12-14 \mathrm{kDa})$ were purchased from Spectrum Laboratories, Inc. (Rancho Dominguez, CA, USA).

\subsection{Methods}

\subsubsection{Chemical Synthesis}

The protocol for the synthesis of $\mathbf{2} \mathbf{a}, \mathbf{2} \mathbf{b}, \mathbf{2} \mathbf{d}, \mathbf{2} \mathbf{f}$ and $\mathbf{3} \mathbf{a}$ was modified from the one-pot reaction reported in the literature with slight adjustment of the ratio of the reagents and reaction time [10,15]. $\mathbf{2} \mathbf{c}, \mathbf{3 b}, \mathbf{3} \mathbf{c}, \mathbf{3 d}$ and $\mathbf{3 e}$ were synthesised using a modified two-step reaction with slight adjustment of the ratio of the reagents and reaction time [24,25].

$N^{2}, N^{2}$-Dimethyl-6-pentadecyl-1,3,5-triazine-2,4-diamine (2a): Metformin hydrochloride (497 mg, $3 \mathrm{mmol}, 3$ equiv.), NaOMe (1 mL, $5 \mathrm{mmol}, 5$ equiv.) and isopropyl palmitate $(350 \mu \mathrm{L}, 1 \mathrm{mmol}, 1$ equiv.) in anh. $\mathrm{MeOH}(4 \mathrm{~mL})$ were mixed and heated under reflux for $2 \mathrm{~h}$. Purification via extraction with EtOAc/ $\mathrm{H}_{2} \mathrm{O}$ and silica gel column chromatography (eluent: 1:3 EtOAc:hexane) yielded 2a as a white solid (225 mg, 64\% yield). ${ }^{1} \mathrm{H}-\mathrm{NMR}$ $\left(400 \mathrm{MHz} \mathrm{CDCl}_{3}\right) \delta 5.17$ (brs, 2H), 3.15 (brs, 3H), 3.11 (brs, 3H), $2.49(\mathrm{t}, J=7.7 \mathrm{~Hz}, 3 \mathrm{H})$, $1.78-1.64(\mathrm{~m}, 2 \mathrm{H}), 1.32-1.19(\mathrm{~m}, 24 \mathrm{H}), 0.87(\mathrm{t}, J=6.7 \mathrm{~Hz}, 3 \mathrm{H}) . ;{ }^{13} \mathrm{C}-\mathrm{NMR}\left(101 \mathrm{MHz}, \mathrm{CDCl}_{3}\right)$ $\delta 178.1,166.3,165.6,38.8,36.3,32.1,29.8,27.722 .8,14.2$. Data are consistent with literature values [43]. 
$\mathrm{N}^{2}, N^{2}$-Dimethyl-6-phenyl-1,3,5-triazine-2,4-diamine (2b): Metformin hydrochloride (497 mg, $3 \mathrm{mmol}, 3$ equiv.), $\mathrm{NaOMe}(1 \mathrm{~mL}, 5 \mathrm{mmol}, 5$ equiv.) and methyl benzoate $(126 \mu \mathrm{L}, 1 \mathrm{mmol}$, 1 equiv.) in anh. $\mathrm{MeOH}(4 \mathrm{~mL})$ were heated under reflux for $2 \mathrm{~h}$. The crude mixture purified by silica gel column chromatography (eluent: 1:2 EtOAc:hexane) yielded $\mathbf{2} \mathbf{b}$ as a white-yellow solid. (112 mg, 52\% yield). ${ }^{1} \mathrm{H}-\mathrm{NMR}\left(400 \mathrm{MHz}, \mathrm{CDCl}_{3}\right) \delta 8.37(\mathrm{~d}, J=7.5 \mathrm{~Hz}, 2 \mathrm{H}), 7.53-7.38(\mathrm{~m}$, 3H), 5.26 (brs, 2H), 3.30 (brs, 3H), 3.17 (brs, 3H); ${ }^{13} \mathrm{C}-\mathrm{NMR}\left(101 \mathrm{MHz}, \mathrm{CDCl}_{3}\right) \delta$ 171.0, 167.4, 166.0, 131.4, 130.1, 128.5, 128.3, 36.4. Data are consistent with literature values [7].

2-(4-Amino-6-(dimethylamino)-1,3,5-triazin-2-yl)phenol (2c): Metformin in the free base form was prepared with the same protocol as $\mathbf{1 b}$ using metformin hydrochloride ( $3.313 \mathrm{~g}$, $20 \mathrm{mmol}, 1$ equiv.) and $\mathrm{NaOMe}(4 \mathrm{~mL}, 20 \mathrm{mmol}, 1$ equiv.) in $15 \mathrm{~mL}$ of anh. MeOH. Next, excess amount of methyl salicylate $(5 \mathrm{~mL})$ was added and heated at $115^{\circ} \mathrm{C}$ for $2 \mathrm{~h}$ with a notable formation of basic fume. Upon the completion of reaction, the crude mixture was acidified with $\mathrm{NH}_{4} \mathrm{Cl}$ to neutral $\mathrm{pH}$ then purified by extraction with $\mathrm{EtOAc} / \mathrm{H}_{2} \mathrm{O}$ and silica gel column chromatography (eluent: 1:3, 1:2 EtOAc:hexane). The product was further purified by recrystallisation using EtOAc and hexane, which yielded $2 \mathrm{c}$ as a greenish yellow solid. (2.153 g, 47\% yield). ${ }^{1} \mathrm{H}-\mathrm{NMR}\left(400 \mathrm{MHz}, \mathrm{CDCl}_{3}\right) \delta 8.33(\mathrm{~d}, J=7.9 \mathrm{~Hz}, 1 \mathrm{H}), 7.37(\mathrm{t}$, $J=7.8 \mathrm{~Hz}, 1 \mathrm{H}), 6.95(\mathrm{~d}, J=8.3 \mathrm{~Hz}, 1 \mathrm{H}), 6.89(\mathrm{t}, J=7.5 \mathrm{~Hz}, 1 \mathrm{H}), 5.21(\mathrm{brs}, 2 \mathrm{H}), 3.22(\mathrm{~s}, 3 \mathrm{H})$, 3.17 (s, 3H); ${ }^{13} \mathrm{C}-\mathrm{NMR}\left(101 \mathrm{MHz}, \mathrm{CDCl}_{3}\right) \delta 171.3,165.8,164.4,162.2,134.1,129.7,119.1$, 118.4, 118.1, 36.9, 36.7; IR (neat): 3390, 3324, 3200, 2926, 1652, 1566, 1499, 1031, 746; HRMS (ESI+): $m / z$ calcd for $\mathrm{C}_{11} \mathrm{H}_{13} \mathrm{~N}_{5} \mathrm{O}[\mathrm{M}+\mathrm{H}]{ }^{+} 232.1198$, found 232.1191; Mp:194-197 ${ }^{\circ} \mathrm{C}$.

(E)-N $N^{2}, N^{2}$-dimethyl-6-styryl-1,3,5-triazine-2,4-diamine (2d): Metformin hydrochloride (331 mg, $2 \mathrm{mmol}, 1$ equiv.), NaOMe ( $800 \mu \mathrm{L}, 4 \mathrm{mmol}, 2$ equiv.), and methyl cinnamate ( $446 \mu \mathrm{L}, 3 \mathrm{mmol}$, 1.5 equiv.) in anh. $\mathrm{MeOH}(4 \mathrm{~mL})$ were stirred under reflux for $3 \mathrm{~h}$. The crude mixture purified by extraction using EtOAc/hexane yielded $\mathbf{2} \mathbf{d}$ as a yellow solid (302 mg, quant.). ${ }^{1} \mathrm{H}-\mathrm{NMR}\left(400 \mathrm{MHz}, \mathrm{CDCl}_{3}\right) \delta 7.95(\mathrm{~d}, J=15.9 \mathrm{~Hz}, 1 \mathrm{H}), 7.58(\mathrm{~d}, J=7.0 \mathrm{~Hz}$, 2H), 7.43-7.30 (m, 3H), $6.83(\mathrm{~d}, J=15.9 \mathrm{~Hz}, 1 \mathrm{H}), 5.28$ (brs, 2H), 3.22 (brs, 3H), 3.15 (brs, $3 \mathrm{H})$; ${ }^{13} \mathrm{C}-\mathrm{NMR}\left(101 \mathrm{MHz}, \mathrm{CDCl}_{3}\right) \delta$ 171.0, 167.2, 166.1, 139.7, 136.3, 129.6, 129.2, 128.3, 127.5, 36.7. Data are consistent with literature values [8].

Methyl 4-amino-6-(dimethylamino)-1,3,5-triazine-2-carboxylate (2e): Metformin in the free base form was prepared with the same protocol as $\mathbf{1 b}$ using metformin hydrochloride (497 mg, $3 \mathrm{mmol}, 1.5$ equiv.) and NaOMe $(400 \mu \mathrm{L}, 2 \mathrm{mmol}, 1$ equiv.) in $6 \mathrm{~mL}$ of anh. $\mathrm{MeOH}$. Metformin dissolved in anh. $\mathrm{MeOH}(7.5 \mathrm{~mL})$ was added dropwise into diethyl oxalate (1218 $\mu \mathrm{L}, 9 \mathrm{mmol}, 3$ equiv.) also dissolved in anh. $\mathrm{MeOH}(7.5 \mathrm{~mL})$ with constant stirring motion at room temperature. Subsequently, the mixture was heated under reflux overnight. The mixture was purified by silica gel column chromatography (eluent: 3:5 EtOAc:hexane), which yielded 2e as a yellow solid (27 mg, 7\% yield). ${ }^{1} \mathrm{H}-\mathrm{NMR}(400 \mathrm{MHz}$, $\left.\mathrm{CDCl}_{3}\right) \delta 5.68$ (brs, 2H), 3.95 (s, 3H), $3.23(\mathrm{~s}, 3 \mathrm{H}), 3.13(\mathrm{~s}, 3 \mathrm{H}) ;{ }^{13} \mathrm{C}-\mathrm{NMR}\left(101 \mathrm{MHz}, \mathrm{CDCl}_{3}\right)$ $\delta$ 166.5, 165.4, 164.0, 163.1, 53.1, 36.4, 36.2; IR (neat): 3426, 3303, 3170, 2953, 1732, 1640, 1566, 1439, 1247, 1209, 1011, 793; HRMS (ESI+): $m / z$ calcd for $\mathrm{C}_{7} \mathrm{H}_{11} \mathrm{~N}_{5} \mathrm{O}_{2}[\mathrm{M}+\mathrm{Na}]^{+} 220.0810$, found 220.0815; Mp:219-221 ${ }^{\circ} \mathrm{C}$.

4-Amino-6-(dimethylamino)-1,3,5-triazine-2-carboxylic acid (2f): Metformin hydrochloride (167 mg, $1 \mathrm{mmol}, 1$ equiv.), NaOMe ( $400 \mu \mathrm{L}, 2 \mathrm{mmol}, 2$ equiv.) and diethyl oxalate ( $2975 \mu \mathrm{L}$, $22 \mathrm{mmol}, 22$ equiv.) in anh. $\mathrm{MeOH}(5 \mathrm{~mL})$ were stirred under reflux for $4 \mathrm{~h}$. The white precipitate was filtered, washed with $\mathrm{MeOH}$ and dried under vacuum to yield $2 \mathbf{2}$ as a white-yellow solid (118 mg, 65\% yield). ${ }^{1} \mathrm{H}-\mathrm{NMR}(400 \mathrm{MHz}, \mathrm{DMSO}) \delta 11.08(\mathrm{~s}, 1 \mathrm{H}), 9.01$ (brs, 1H), 8.02 (brs, 1H), 3.11 (s, 3H), 3.02 (s, 3H); ${ }^{13} \mathrm{C}-\mathrm{NMR}$ (101 MHz, DMSO) $\delta$ 171.2, 169.9, 163.8, 160.4, 37.9, 37.2; IR (neat): 3304, 3168, 1763, 1708, 1563, 1479, 1324, 1040, 819; HRMS (ESI+): $m / z$ calcd for $\mathrm{C}_{6} \mathrm{H}_{9} \mathrm{~N}_{5} \mathrm{O}_{2}[\mathrm{M}+\mathrm{Na}]^{+} 206.0654$, found 206.0645; Mp: $>300{ }^{\circ} \mathrm{C}$.

6-pentadecyl- $N^{2}$-phenyl-1,3,5-triazine-2,4-diamine (3a): $1 \mathbf{a}(6.410 \mathrm{~g}, 30 \mathrm{mmol}, 3$ equiv.), $\mathrm{NaOMe}(10 \mathrm{~mL}, 50 \mathrm{mmol}, 5$ equiv.) and isopropyl palmitate (10.511 mL, $30 \mathrm{mmol}, 3$ equiv.) in anh. $\mathrm{MeOH}(40 \mathrm{~mL})$ were stirred under reflux for $2 \mathrm{~h}$. Purification via extraction with EtOAc $/ \mathrm{H}_{2} \mathrm{O}$ and silica gel column chromatography (eluent: 1:3, 1:2 EtOAc:hexane) yielded 
3a as a white solid (5.0 g, 42\% yield). ${ }^{1} \mathrm{H}-\mathrm{NMR}(400 \mathrm{MHz}, \mathrm{DMSO}) \delta 9.38(\mathrm{~s}, 1 \mathrm{H}), 7.77$ (d, $J=7.9 \mathrm{~Hz}, 2 \mathrm{H}), 7.24(\mathrm{t}, J=7.9 \mathrm{~Hz}, 2 \mathrm{H}), 6.94(\mathrm{t}, J=7.2 \mathrm{~Hz}, 3 \mathrm{H}), 2.41(\mathrm{t}, J=7.6 \mathrm{~Hz}, 2 \mathrm{H})$, $1.73-1.60(\mathrm{~m}, 2 \mathrm{H}), 1.29-1.20(\mathrm{~m}, 23 \mathrm{H}), 0.84(\mathrm{t}, J=6.7 \mathrm{~Hz}, 3 \mathrm{H}) ;{ }^{13} \mathrm{C}-\mathrm{NMR}(101 \mathrm{MHz}, \mathrm{DMSO})$ $\delta 177.8,166.6,164.2,140.0,128.3,121.7,119.7,37.9,31.2,29.0,26.9,22.0,13.9$; IR (neat): 3462, 3311, 3106, 2913, 2848, 1655, 1626, 1528, 1470, 1429, 1385, 1028, 815, 747, 720, 699; HRMS (ESI+): $m / z$ calcd for $\mathrm{C}_{24} \mathrm{H}_{39} \mathrm{~N}_{5}[\mathrm{M}+\mathrm{H}]{ }^{+}$398.3284, found $398.3291 ; \mathrm{Mp}: 118-121^{\circ} \mathrm{C}$.

$N^{2}$,6-diphenyl-1,3,5-triazine-2,4-diamine (3b): $\mathbf{1 b}$ was used without further purification. Methyl benzoate (792 $\mu \mathrm{L}, 6 \mathrm{mmol}, 2$ equiv.) was added into $\mathbf{1 b}$ (532 mg, 3 mmol, 1 equiv.) dissolved in anh. MeOH (4 mL). The mixture was stirred under reflux for $24 \mathrm{~h}$. Purified by silica gel column chromatography (eluent: 1:3 EtOAc:hexane) yielded $3 \mathbf{b}$ as a yellow solid (54 mg, 7\% yield). ${ }^{1} \mathrm{H}-\mathrm{NMR}(400 \mathrm{MHz}, \mathrm{DMSO}) \delta 9.52(\mathrm{~s}, 1 \mathrm{H}), 8.31$ (d, J = 6.8 Hz, 2H), $7.84(\mathrm{~d}, J=8.0 \mathrm{~Hz}, 2 \mathrm{H}), 7.58-7.44(\mathrm{~m}, 3 \mathrm{H}), 7.31(\mathrm{t}, J=7.8 \mathrm{~Hz}, 2 \mathrm{H}), 7.12(\mathrm{brs}, 2 \mathrm{H}), 6.99(\mathrm{t}$, $J=7.3 \mathrm{~Hz}, 1 \mathrm{H}) ;{ }^{13} \mathrm{C}-\mathrm{NMR}(101 \mathrm{MHz}, \mathrm{DMSO}) \delta 170.7,167.6,165.1,140.3,137.2,131.8,128.9$, $128.7,128.2,122.5,120.4$. Data is consistent with literature values [44].

2-(4-amino-6-(phenylamino)-1,3,5-triazin-2-yl)phenol (3c): $\mathbf{1 b}$ was used without further purification. A mixture of $\mathbf{1 b}(355 \mathrm{mg}, 2 \mathrm{mmol}, 1$ eqiv.) and an excess amount of methyl salicylate $(500 \mu \mathrm{L})$ was stirred and heated at $115^{\circ} \mathrm{C}$ for $7 \mathrm{~h}$ with a notable formation of basic fume. Upon the completion of reaction, the crude mixture was acidified with $\mathrm{NH}_{4} \mathrm{Cl}$ to neutral $\mathrm{pH}$ then purified by extraction with EtOAc/ $\mathrm{H}_{2} \mathrm{O}$ and silica gel column chromatography (eluent: 1:4-1:2 EtOAc:hexane). The product was further purified by recrystallisation using EtOAc and hexane, which yielded $3 \mathrm{c}$ as a greenish yellow solid (220 mg, 39\% yield). ${ }^{1} \mathrm{H}-\mathrm{NMR}(400 \mathrm{MHz}, \mathrm{DMSO}) \delta 13.49$ (s, 1H), 9.77 (brs, 1H), 8.26 (d, $J=7.3 \mathrm{~Hz}, 1 \mathrm{H}), 7.76$ (brs, 2H), 7.55 (brs, 1H), $7.44-7.35(\mathrm{~m}, 2 \mathrm{H}), 7.33(\mathrm{t}, J=7.2 \mathrm{~Hz}, 2 \mathrm{H}), 7.04$ $(\mathrm{t}, J=7.5 \mathrm{~Hz}, 1 \mathrm{H}), 6.90(\mathrm{t}, J=8.0 \mathrm{~Hz}, 2 \mathrm{H}) ;{ }^{13} \mathrm{C}-\mathrm{NMR}(101 \mathrm{MHz}, \mathrm{DMSO}) \delta 169.9,164.7,160.8$, $138.8,133.2,128.3,128.1,122.3,120.2,117.9,117.2,117.1$; IR (neat): 3475, 3302, 3181, 1667, 1595, 1533, 1443 1429, 1031, 811, 752, 691; HRMS (ESI+): $m / z$ calcd for $\mathrm{C}_{15} \mathrm{H}_{13} \mathrm{~N}_{5} \mathrm{O}[\mathrm{M}+\mathrm{H}]^{+}$ 280.1198, found 280.1205; Mp: 222-224 ${ }^{\circ} \mathrm{C}$.

(E)-N $N^{2}$-phenyl-6-styryl-1,3,5-triazine-2,4-diamine (3d): $\mathbf{1 b}$ was used without further purification. Methyl cinnamate $(447 \mu \mathrm{L}, 3 \mathrm{mmol}, 1$ equiv.) was added into $\mathbf{1 b}$ (709 mg, $4 \mathrm{mmol}$, 1.33 equiv.) dissolved in anh. $\mathrm{MeOH}(4 \mathrm{~mL})$. The mixture was stirred under reflux for $24 \mathrm{~h}$. Purification by silica gel column chromatography (eluent: 1:2, 1:1 EtOAc:hexane) yielded $3 \mathrm{~d}$ as a yellow solid $(154 \mathrm{mg}, 17 \%$ yield $) .{ }^{1} \mathrm{H}-\mathrm{NMR}(500 \mathrm{MHz}) \delta 9.47(\mathrm{~s}, 1 \mathrm{H}), 7.87$ $(\mathrm{d}, J=15.9 \mathrm{~Hz}, 1 \mathrm{H}), 7.81(\mathrm{dd}, J=8.7,1.2 \mathrm{~Hz}, 2 \mathrm{H}), 7.66(\mathrm{~d}, J=7.5 \mathrm{~Hz}, 2 \mathrm{H}), 7.46-7.36(\mathrm{~m}$, $3 \mathrm{H}), 7.28(\mathrm{t}, J=7.6 \mathrm{~Hz}, 2 \mathrm{H}), 7.03(\mathrm{brs}, 2 \mathrm{H}), 6.97(\mathrm{tt}, J=7.3,1.2 \mathrm{~Hz}, 1 \mathrm{H}), 6.82(\mathrm{~d}, J=16.0 \mathrm{~Hz}$, $1 \mathrm{H}) ;{ }^{13} \mathrm{C}-\mathrm{NMR}\left(101 \mathrm{MHz}, \mathrm{CDCl}_{3}\right) \delta 171.0,166.6,164.3,141.2,138.3,135.5,129.9,129.1$, 129.0, 128.2, 125.5, 124.0, 121.0; IR (neat): 3462, 3276, 3058, 1638, 1574, 1526, 1490, 1442, 970, 735, 691; HRMS (ESI+): $m / z$ calcd for $\mathrm{C}_{17} \mathrm{H}_{15} \mathrm{~N}_{5}[\mathrm{M}+\mathrm{H}]+2$ 290.1406, found 290.1409; Mp: $186-189^{\circ} \mathrm{C}$.

Methyl 4-amino-6-(phenylamino)-1,3,5-triazine-2-carboxylate (3e): $\mathbf{1 b}$ was used without further purification. $\mathbf{1 b}(4.430 \mathrm{~g}, 25 \mathrm{mmol}, 1$ equiv. $)$ dissolved in anh. $\mathrm{MeOH}(62.5 \mathrm{~mL})$ was added dropwise into diethyl oxalate $(10.15 \mathrm{~mL}, 75 \mathrm{mmol}, 3$ equiv.) also dissolved in anh. $\mathrm{MeOH}(62.5 \mathrm{~mL})$ with constant stirring motion at room temperature. Subsequently, the mixture was stirred under reflux for $14 \mathrm{~h}$. Purification by silica gel column chromatography (eluent: 1:1 EtOAc/hexane to 5\% EtOAc/MeOH) yielded 3e as a yellow solid (2.428 g, 40\% yield). ${ }^{1} \mathrm{H}-\mathrm{NMR}(400 \mathrm{MHz}, \mathrm{DMSO}) \delta 9.93$ (brs, $\left.1 \mathrm{H}\right), 7.78$ (d, J = 7.9 Hz, 2H), 7.56 (brs, 1H), 7.43 (brs, 1H), $7.28(\mathrm{t}, J=6.8 \mathrm{~Hz}, 2 \mathrm{H}), 7.01(\mathrm{t}, J=7.9 \mathrm{~Hz}, 1 \mathrm{H}), 3.83(\mathrm{~s}, 3 \mathrm{H})$; ${ }^{13} \mathrm{C}-\mathrm{NMR}$ (101 MHz, DMSO) $\delta$ 167.3, 164.5, 164.2, 164.1, 139.5, 128.7, 122.7, 120.3, 52.6. Data are consistent with literature values [29].

4-amino-6-(phenylamino)-1,3,5-triazine-2-carboxylic acid (3f) was synthesised using a modified protocol from the literature [45]: $\mathrm{NaOH}$ (aq.) $(50 \mathrm{~mL}, 1 \mathrm{M})$ was added to a solution of $3 \mathbf{e}(2.023 \mathrm{~g}, 8.25 \mathrm{mmol})$ dissolved in $\mathrm{EtOH}(100 \mathrm{~mL})$. The mixture was stirred under reflux for $3 \mathrm{~h}$, cooled to room temperature, followed by the addition of $\mathrm{HCl}$ (aq.) 
(50 mL, 1M). The resulting precipitate was filtered, washed with DI and dried under vacuum to yield $3 \mathrm{f}$ as a pale-yellow solid (2.416 g, quant.). ${ }^{1} \mathrm{H}-\mathrm{NMR}$ (400 MHz, DMSO) $\delta$ 9.89 (brs, 1H), $7.78(\mathrm{~d}, J=8.1 \mathrm{~Hz}, 2 \mathrm{H}), 7.47$ (brs, 2H), $7.28(\mathrm{t}, J=7.3 \mathrm{~Hz}, 2 \mathrm{H}), 7.00(\mathrm{t}, J=7.5$, $6.7 \mathrm{~Hz}, 1 \mathrm{H}) ;{ }^{13} \mathrm{C}-\mathrm{NMR}(101 \mathrm{MHz}, \mathrm{DMSO}) \delta 166.9,165.4,165.0,164.3,139.4,128.5,122.6$, 120.2; IR (neat): 3319, 3129, 1675, 1622, 1594, 1568, 1489, 1451, 1005, 788, 761, 691; HRMS (ESI+): $m / z$ calcd for $\mathrm{C}_{10} \mathrm{H}_{9} \mathrm{~N}_{5} \mathrm{O}_{2}[\mathrm{M}+2 \mathrm{Na}-\mathrm{H}]{ }^{+} 276.0473$, found 276.0473 ; Mp: $248-249{ }^{\circ} \mathrm{C}$.

\subsubsection{Characterisation of 1,3,5-Triazine Derivatives}

${ }^{1} \mathrm{H}$ and ${ }^{13} \mathrm{C}$-NMR were recorded with Bruker Avance (III) $400 \mathrm{WB}$ spectrometer $(400 \mathrm{mHz})$ and JEOL JNM-ECZS NMR spectrometer (500 mHz); FTIR spectra were analysed by Thermo Scientific ${ }^{\mathrm{TM}}$ Nicolet 6700 FT-IR Spectrometer with ATR mode (32 scans); high-resolution mass spectra (HRMS) were recorded with micrOTOF-Q II mass spectrometer (Bruker Daltonics) with electrospray ionization; and melting points (Mp) were measured using a Stuart SMP20 melting point apparatus.

\subsubsection{In vitro Anticancer Activity of 1,3,5-Triazine Derivatives}

HCT116 were cultured in a growth medium of RPMI. SW620 were cultured in a growth medium of DMEM. Both cell culture mediums were supplemented with $10 \%$ FBS and $1 \%$ antibiotic, and the cells were maintained in an incubator at $37^{\circ} \mathrm{C}$ in a humidified atmosphere of $5 \% \mathrm{CO}_{2}$.

HCT116 and SW620 were seeded in 96-well plates at a density of $1 \times 10^{4}$ per well in cell culture medium and incubated for $24 \mathrm{~h}$ to allow cell adherence. Cells were treated with the synthesised 1,3,5-triazine derivatives at concentration between $0-100 \mu \mathrm{M}$ for $48 \mathrm{~h}$. Following incubation, $10 \mu \mathrm{L}$ PrestoBlue ${ }^{\mathrm{TM}}$ solution was added to each well, and then plates were placed back into the incubator for a further $30 \mathrm{~min}$ incubation [46]. Fluorescence was measured using a microplate reader at $560 \mathrm{~nm}$ excitation and $590 \mathrm{~nm}$ emission (Thermo, Varioskan Flash, England). The results were analysed by one-way ANOVA and Tukey post-test using GraphPad Prism 5.0 (Graph-Pad Software Inc., San Diego, CA, USA).

3.2.4. Preparation of 1,3,5-Triazine Incorporated Calcium Citrate Nanoparticles (Condition $\mathrm{A}-\mathrm{C})$

Solution A: citric acid was first dissolved in DI water, followed by the addition of $1 \mathrm{M}$ $\mathrm{NaOH}$ until $\mathrm{pH}$ of solution reached $\mathrm{pH} 6.0$ then the volume was adjusted to $5 \mathrm{~mL}$ with EtOH.; Solution B: 2a was dissolved in $5 \mathrm{~mL}$ EtOH while heating at 50-60 ${ }^{\circ} \mathrm{C}$.; Solution C: calcium chloride was dissolved in $5 \mathrm{~mL}$ EtOH. Solution A was added into solution B which turned cloudy straightaway. EtOH and DI water were added to the mixture to obtain a clear solution. Solution $\mathrm{C}$ was added into the $\mathrm{AB}$ mixture with vigorous stirring then moved to stir at room temperature for 2,5 or $8 \mathrm{~h}$. The white suspension was centrifuged, washed with $\mathrm{EtOH} / \mathrm{DI}$ water and freeze dried for $24 \mathrm{~h}$.

\subsubsection{Characterisation of 1,3,5-Triazine Incorporated Calcium Citrate Nanoparticles}

Size and morphology of the synthesised products were recorded with JEOL JSM$6480 \mathrm{LV}$ scanning electron microscope at $15 \mathrm{kV}$; hydrodynamic size and zeta potential were measured with the Zetasizer Nano ZS, Malvern Instrument (IR of 1.660); functional groups were analysed by Thermo Scientific ${ }^{\mathrm{TM}}$ Nicolet 6700 FT-IR Spectrometer (Thermo Fisher Scientific, Waltham, MA, USA) with ATR mode; chemical changes or decomposition temperature by Perkin Elmer Pyris ${ }^{\mathrm{TM}} 1$ TGA; elemental analysis by Thermo Flash $2000 \mathrm{CHNS} / \mathrm{O}$ analyser; and \%cumulative drug release was measured with UV/Vis spectrometer (Hewlett Packard 8453, Agilent Technology, Santa Clara, CA, USA).

\subsubsection{Drug Release Study}

The drug release profile of the synthesised nanoparticles was determined by the dialysis method carried out at $37^{\circ} \mathrm{C}$ and stirring speed of $100 \mathrm{rpm}$. Thirty percent $(v / v)$ of EtOH in PBS at pH 3.0, 5.0 and 7.4 were used as the release medium [40]. Nanoparticles 
(weight equivalent to $1 \mathrm{mg}$ of $\mathbf{2 a}$ ) were dispersed in $10 \mathrm{~mL} \mathrm{30 \% (v/v)} \mathrm{EtOH/PBS} \mathrm{at}$ $\mathrm{pH}$ 3.0, 5.0 and 7.4. The dialysis bag was immersed into $190 \mathrm{~mL}$ of release medium. At predetermined time, the dialysis bag was moved into another container with $190 \mathrm{~mL}$ of fresh release medium [22]. To extract $\mathbf{2 a}$ out of the release medium, the solution was evaporated under vacuum to remove $\mathrm{EtOH}$ and extracted with dichloromethane [47]. For the UV-Vis spectroscopy measurement, $10 \mathrm{~mL}$ of $60 \% \mathrm{EtOH} / \mathrm{PBS}$ acidified with $\mathrm{HCl}$ to $\mathrm{pH} 3.0,5.0$ and 7.4 was added to each sample and measured at 200-320 nm. The calibration curve was drawn using a standard which was 2a dissolved in 60\% EtOH/PBS at various concentrations.

\section{Conclusions}

In conclusion, we have reported a new study that integrated drug discovery with drug delivery. Twelve 1,3,5-triazine derivatives of metformin (2a-2f $)$ and phenylbiguanide (3a-3f) were synthesised via two pathways using various esters. The anticancer activity of the derivatives ranged widely depending on the hydrophobicity of the substituent. It was found that some of the derivatives were more potent as anticancer agents with $\mathrm{IC}_{50}$ comparable to the values of the reference drug, cisplatin. The optimisation for the preparation of CaCit-2a NPs under EtOH-water binary solvent system revealed that the use of 1:2 citric acid/ $\mathrm{NaOH}$ as the citrate source with a reaction time of $8 \mathrm{~h}$ provided the best result. The obtained nanoparticles had appropriate size satisfying the EPR effect, moderate \%drug loading, as well as showing a controlled drug release behaviour under pH 5.0 environment. The knowledge from both the biological evaluations and the DDS studies could be valuable for further development of triazine-based anticancer drug and could serve as a platform for potential calcium citrate nanoparticles drug delivery system in the future.

Supplementary Materials: The following are available online, ${ }^{1} \mathrm{H}$ and ${ }^{13} \mathrm{C}-\mathrm{NMR}$ spectra for compounds 1a, 1b, 2a-2f and 3a-3f; IR and HRMS spectra for compound 2c, 2e, 2f, 3a, 3c, 3d, and 3f; biological evaluations of $\mathbf{2 a}-\mathbf{2 f}$ and 3a-3f; size distribution graphs for Condition A and C.

Author Contributions: Conceptualization, R.R. and T.K.; methodology, M.C. and S.C.; validation, A.S., R.R. and T.K.; formal analysis, S.C., M.C. and T.K.; investigation, M.C.; resources, A.S., R.R. and T.K.; data curation, M.C.; writing-original draft preparation, M.C.; writing-review and editing, R.R. and T.K.; project administration, T.K.; funding acquisition, R.R. and T.K. All authors have read and agreed to the published version of the manuscript.

Funding: The research grant funds have been provided by Chulalongkorn University: CU_GR_63_159_23_25, the 72nd Anniversary of His Majesty King Bhumibol Adulyadej Scholarship, and the 90th Anniversary Chulalongkorn University Fund (Ratchadapiseksomphot Endowment Fund).

Data Availability Statement: Data is contained within the article or Supplementary Material.

Acknowledgments: Special thanks to members of the RR Lab and TK Lab at the Faculty of Science, and Nanomedicine RU at the Faculty of Medicine, Chulalongkorn University for their assistances throughout this project.

Conflicts of Interest: The authors declare no conflict of interest.

Sample Availability: Samples of the compounds 2a, 2 c, and $3 \mathbf{c}$ are available from the authors.

\section{References}

1. Siegel, R.L.; Miller, K.D.; Jemal, A. Cancer statistics, 2019. Ca: Cancerj. Clin. 2019, 69, 7-34. [CrossRef] [PubMed]

2. Das, M.; Mohanty, C.; Sahoo, S.K. Ligand-based targeted therapy for cancer tissue. Expert Opin. Drug Deliv. 2009, 6, $285-304$. [CrossRef]

3. Banerjee, A.; Pathak, S.; Subramanium, V.D.; Dharanivasan, G.; Murugesan, R.; Verma, R.S. Strategies for targeted drug delivery in treatment of colon cancer: Current trends and future perspectives. Drug Discov. Today 2017, 22, 1224-1232. [CrossRef] [PubMed]

4. Singla, P.; Luxami, V.; Paul, K. Synthesis and in vitro evaluation of novel triazine analogues as anticancer agents and their interaction studies with bovine serum albumin. Eur. J. Med. Chem. 2016, 117, 59-69. [CrossRef] [PubMed] 
5. Junaid, A.; Lim, F.P.L.; Tiekink, E.R.T.; Dolzhenko, A.V. Design, synthesis, and biological evaluation of new 6,N2-diaryl-1,3,5triazine-2,4-diamines as anticancer agents selectively targeting triple negative breast cancer cells. Rsc Adv. 2020, 10, 25517-25528. [CrossRef]

6. Junaid, A.; Lim, F.P.L.; Tiekink, E.R.T.; Dolzhenko, A.V. New One-Pot Synthesis of 1,3,5-Triazines: Three-Component Condensation, Dimroth Rearrangement, and Dehydrogenative Aromatization. Acs Comb. Sci. 2019, 21, 548-555. [CrossRef]

7. Zeng, M.; Wang, T.; Cui, D.-M.; Zhang, C. Ruthenium-catalyzed synthesis of tri-substituted 1,3,5-triazines from alcohols and biguanides. Newj. Chem. 2016, 40, 8225-8228. [CrossRef]

8. Zeng, M.; Xie, Z.P.; Cui, D.-M.; Zhang, C. Ruthenium-catalyzed synthesis of arylethyl 1,3,5-triazines from arylallyl alcohols and biguanides. Org. Biomol. Chem. 2018, 16, 6140-6145. [CrossRef] [PubMed]

9. Xu, Y.; Shen, B.; Liu, L.; Qiao, C. Metal free [4+1] and [5+1] annulation reactions to prepare heterocycles using DMF and its derivatives as one-carbon source. Tetrahedron Lett. 2020, 61, 151844. [CrossRef]

10. Cao, H.; Liao, S.; Zhong, W.; Xiao, X.; Zhu, J.; Li, W.; Wu, X.; Feng, Y. Synthesis, Characterization, and Biological Evaluations of 1,3,5-Triazine Derivatives of Metformin Cyclization with Berberine and Magnolol in the Presence of Sodium Methylate. Molecules 2017, 22, 1752. [CrossRef] [PubMed]

11. Makowska, A.; Saczewski, F.; Bednarski, P.J.; Sączewski, J.; Balewski, Ł. Hybrid Molecules Composed of 2,4-Diamino-1,3,5triazines and 2-Imino-Coumarins and Coumarins. Synthesis and Cytotoxic Properties. Molecules 2018, 23, 1616. [CrossRef]

12. Chaurasia, S.R.; Dange, R.; Bhanage, B.M. Graphene oxide as a carbo-catalyst for the synthesis of tri-substituted 1,3,5-triazines using biguanides and alcohols. Catal. Commun. 2020, 137, 105933. [CrossRef]

13. Yao, W.; Duan, Z.-C.; Zhang, Y.; Sang, X.; Xia, X.-F.; Wang, D. Iridium Supported on Phosphorus-Doped Porous Organic Polymers: Active and Recyclable Catalyst for Acceptorless Dehydrogenation and Borrowing Hydrogen Reaction. Adv. Synth. Catal. 2019, 361, 5695-5703. [CrossRef]

14. Koh, M.; Lee, J.-C.; Min, C.; Moon, A. A novel metformin derivative, HL010183, inhibits proliferation and invasion of triplenegative breast cancer cells. Bioorg. Med. Chem. 2013, 21, 2305-2313. [CrossRef] [PubMed]

15. Kothayer, H.; Spencer, S.M.; Tripathi, K.; Westwell, A.D.; Palle, K. Synthesis and in vitro anticancer evaluation of some 4,6diamino-1,3,5-triazine-2-carbohydrazides as Rad6 ubiquitin conjugating enzyme inhibitors. Bioorg. Med. Chem. Lett. 2016, 26, 2030-2034. [CrossRef] [PubMed]

16. Torchilin, V. Tumor delivery of macromolecular drugs based on the EPR effect. Adv. Drug Deliv. Rev. 2011, 63, 131-135. [CrossRef] [PubMed]

17. Hickey, J.W.; Santos, J.L.; Williford, J.-M.; Mao, H.-Q. Control of polymeric nanoparticle size to improve therapeutic delivery. J. Control. Release 2015, 219, 536-547. [CrossRef] [PubMed]

18. Bae, Y.H.; Park, K. Targeted drug delivery to tumors: Myths, reality and possibility. J. Control. Release 2011, 153, 198-205. [CrossRef]

19. Estrella, V.; Chen, T.; Lloyd, M.; Wojtkowiak, J.; Cornnell, H.H.; Ibrahim-Hashim, A.; Bailey, K.; Balagurunathan, Y.; Rothberg, J.M.; Sloane, B.F.; et al. Acidity Generated by the Tumor Microenvironment Drives Local Invasion. Cancer Res. 2013, 73, 1524. [CrossRef]

20. Zhang, W.; Wang, W.; Chen, Q.-Y.; Lin, Z.-Q.; Cheng, S.-W.; Kou, D.-Q.; Ying, X.-Z.; Shen, Y.; Cheng, X.-J.; Nie, P.-F.; et al. Effect of calcium citrate on bone integration in a rabbit femur defect model. Asian Pac. J. Trop. Med. 2012, 5, 310-314. [CrossRef]

21. Li, J.; Liu, Y.; Gao, Y.; Zhong, L.; Zou, Q.; Lai, X. Preparation and properties of calcium citrate nanosheets for bone graft substitute. Bioengineered 2016, 7, 376-381. [CrossRef] [PubMed]

22. Oungeun, P.; Rojanathanes, R.; Pinsornsak, P.; Wanichwecharungruang, S. Sustaining Antibiotic Release from a Poly(methyl methacrylate) Bone-Spacer. Acs Omega 2019, 4, 14860-14867. [CrossRef]

23. Rimsueb, N.; Cherdchom, S.; Aksornkitti, V.; Khotavivattana, T.; Sereemaspun, A.; Rojanathanes, R. Feeding Cells with a Novel “Trojan" Carrier: Citrate Nanoparticles. Acs Omega 2020, 5, 7418-7423. [CrossRef] [PubMed]

24. Kothayer, H.; Morelli, M.; Brahemi, G.; Elshanawani, A.A.; Abu Kull, M.E.; El-Sabbagh, O.I.; Shekhar, M.P.V.; Westwell, A.D. Optimised synthesis of diamino-triazinylmethyl benzoates as inhibitors of Rad6B ubiquitin conjugating enzyme. Tetrahedron Lett. 2014, 55, 7015-7018. [CrossRef]

25. Shapiro, S.L.; Parrino, V.A.; Freedman, L. Guanamines. VIII. 6-(Substituted Phenyl)guanamines. J. Org. Chem. 1961, 26, 3331-3334. [CrossRef]

26. Mallon, R.; Feldberg, L.R.; Lucas, J.; Chaudhary, I.; Dehnhardt, C.; Santos, E.D.; Chen, Z.; dos Santos, O.; Ayral-Kaloustian, S.; Venkatesan, A.; et al. Antitumor Efficacy of PKI-587, a Highly Potent Dual PI3K/mTOR Kinase Inhibitor. Clin. Cancer Res. 2011, 17, 3193. [CrossRef]

27. Moreno, L.M.; Quiroga, J.; Abonia, R.; Ramírez-Prada, J.; Insuasty, B. Synthesis of New 1,3,5-Triazine-Based 2-Pyrazolines as Potential Anticancer Agents. Molecules 2018, 23, 1956. [CrossRef] [PubMed]

28. Zhou, J.; Li, P.; Xue, X.; He, S.; Kuang, Y.; Zhao, H.; Chen, S.; Zhi, Q.; Guo, X. Salinomycin induces apoptosis in cisplatin-resistant colorectal cancer cells by accumulation of reactive oxygen species. Toxicol. Lett. 2013, 222, 139-145. [CrossRef] [PubMed]

29. Kothayer, H.; Elshanawani, A.A.; Abu Kull, M.E.; El-Sabbagh, O.I.; Shekhar, M.P.V.; Brancale, A.; Jones, A.T.; Westwell, A.D. Design, synthesis and in vitro anticancer evaluation of 4,6-diamino-1,3,5-triazine-2-carbohydrazides and -carboxamides. Bioorg. Med. Chem. Lett. 2013, 23, 6886-6889. [CrossRef]

30. Peng, H.; Li, K.; Wang, T.; Wang, J.; Wang, J.; Zhu, R.; Sun, D.; Wang, S. Preparation of hierarchical mesoporous CaCO3 by a facile binary solvent approach as anticancer drug carrier for etoposide. Nanoscale Res. Lett. 2013, 8, 321. [CrossRef] [PubMed] 
31. Li, J.F.; Gao, Y.; Zhong, L.Z.; Liu, Y.Q.; Liu, H.Q.; Zou, Q.; Lai, X.F. Facile Self-Assembly Synthesis of Hierarchical 3D Flowerlike Calcium Citrate Microspheres. J. Nano Res. 2017, 45, 185-192. [CrossRef]

32. Garcia, A.C.; Vavrusova, M.; Skibsted, L.H. Supersaturation of calcium citrate as a mechanism behind enhanced availability of calcium phosphates by presence of citrate. Food Res. Int. 2018, 107, 195-205. [CrossRef]

33. Um, N.; Hirato, T. Precipitation behavior of $\mathrm{Ca}(\mathrm{OH})_{2}, \mathrm{Mg}(\mathrm{OH})_{2}$, and $\mathrm{Mn}(\mathrm{OH})_{2}$ from $\mathrm{CaCl}_{2}, \mathrm{MgCl}_{2}$, and $\mathrm{MnCl}_{2}$ in $\mathrm{NaOH}_{2} \mathrm{H}_{2} \mathrm{O}$ solutions and study of lithium recovery from seawater via two-stage precipitation process. Hydrometallurgy 2014, 146, 142-148. [CrossRef]

34. Al-Khaldi, M.H.; Nasr-El-Din, H.A.; Mehta, S.; Al-Aamri, A.D. Reaction of citric acid with calcite. Chem. Eng. Sci. 2007, 62, 5880-5896. [CrossRef]

35. Ma, C.; Gerhard, E.; Lu, D.; Yang, J. Citrate chemistry and biology for biomaterials design. Biomaterials 2018, 178, 383-400. [CrossRef] [PubMed]

36. Iafisco, M.; Ramírez-Rodríguez, G.B.; Sakhno, Y.; Tampieri, A.; Martra, G.; Gómez-Morales, J.; Delgado-López, J.M. The growth mechanism of apatite nanocrystals assisted by citrate: Relevance to bone biomineralization. CrystEngComm 2015, 17, 507-511. [CrossRef]

37. Xiao, H.; Hu, C.; Chen, C.; Tao, C.; Wu, Y.; Jiang, J. The advantage of alcohol-calcium method on the formation and the stability of vaterite against ethanol-water binary solvent method. J. Mater. Res. 2020, 35, 289-298. [CrossRef]

38. Sand, K.K.; Rodriguez-Blanco, J.D.; Makovicky, E.; Benning, L.G.; Stipp, S.L.S. Crystallization of CaCO 3 in Water-Alcohol Mixtures: Spherulitic Growth, Polymorph Stabilization, and Morphology Change. Cryst. Growth Des. 2012, 12, 842-853. [CrossRef]

39. Hebeish, A.; El-Rafie, M.H.; El-Sheikh, M.A.; El-Naggar, M.E. Ultra-Fine Characteristics of Starch Nanoparticles Prepared Using Native Starch With and Without Surfactant. J. Inorg Organomet Polym Mater. 2014, 24, 515-524. [CrossRef]

40. Hardiansyah, A.; Yang, M.-C.; Liu, T.-Y.; Kuo, C.-Y.; Huang, L.-Y.; Chan, T.-Y. Hydrophobic Drug-Loaded PEGylated Magnetic Liposomes for Drug-Controlled Release. Nanoscale Res. Lett. 2017, 12, 355. [CrossRef] [PubMed]

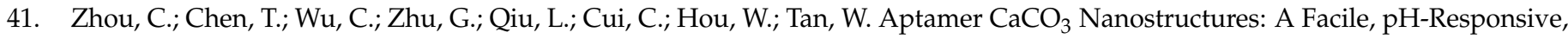
Specific Platform for Targeted Anticancer Theranostics. Chem. Asianj. 2015, 10, 166-171. [CrossRef] [PubMed]

42. Guo, Y.; Li, H.; Shi, W.; Zhang, J.; Feng, J.; Yang, X.; Wang, K.; Zhang, H.; Yang, L. Targeted delivery and pH-responsive release of doxorubicin to cancer cells using calcium carbonate/hyaluronate/glutamate mesoporous hollow spheres. J. Colloid Interface Sci. 2017, 502, 59-66. [CrossRef] [PubMed]

43. Liu, C. Synthesis of the derivatives of 2-Amino-4-dimethylamino-1,3,5-triazine. J. Guangdong Coll. Pharm. 2005, $21,2$.

44. Liu, C.; Lin, J.; Leftheris, K. A novel one-pot synthesis of N,6-disubstituted 1,3,5-triazine-4,6-diamines from isothiocyanates and amidines. Tetrahedron Lett. 2007, 48, 435-437. [CrossRef]

45. Lebel, O.; Perron, M.-È.; Maris, T.; Zalzal, S.F.; Nanci, A.; Wuest, J.D. A New Class of Selective Low-Molecular-Weight Gelators Based on Salts of Diaminotriazinecarboxylic Acids. Chem. Mater. 2006, 18, 3616-3626. [CrossRef]

46. Xu, M.; McCanna, D.J.; Sivak, J.G. Use of the viability reagent PrestoBlue in comparison with alamarBlue and MTT to assess the viability of human corneal epithelial cells. J. Pharmacol. Toxicol. Methods 2015, 71, 1-7. [CrossRef]

47. Wu, J.-L.; Wang, C.-Q.; Zhuo, R.-X.; Cheng, S.-X. Multi-drug delivery system based on alginate/calcium carbonate hybrid nanoparticles for combination chemotherapy. Colloids Surf. B 2014, 123, 498-505. [CrossRef] 